\title{
Journal of Finance Research
}

https://ojs.s-p.sg/index.php/jfr

\section{The Concrete Analysis of the Change of Import and Export Trade of Chinese Enterprises Is Based on the Perspective of RMB Exchange Rate}

\section{Chao Gao*}

Zhejiang International Studies University, Hangzhou, Zhejiang, 310000, China

\begin{tabular}{l}
\hline ARTICLE INFO \\
\hline Article history \\
Received: 29 March 2021 \\
Revised: 1 April 2021 \\
Accepted: 9 April 2021 \\
Published Online: 16 April 2021 \\
\hline
\end{tabular}

\section{Keywords:}

Import and export trade

The yuan

Exchange rate

Appreciation

Devaluation

\section{Introduction}

The study of exchange rate fluctuations can better help Chinese enterprises to get new development in foreign trade, mainly to do a good job of risk aversion and adjust product structure according to the appreciation and depreciation of the RMB. After China's reform and opening up, China gradually integrate with the world market, the RMB exchange rate through the two significant changes, also in 1994 the RMB exchange rate system, the official exchange rate and market in 2005 and the floating exchange rate system reform, two foreign currency exchange difference for the reform and the renminbi in the subsequent years have caused huge impact to our country enterprise

\section{ABSTRACT}

The change of import and export trade of Chinese enterprises actually reflects the appreciation and depreciation of RMB, which are closely related to the total volume of import and export trade of Chinese enterprises and the formulation of corresponding foreign exchange measures. Generally speaking, the rise of the RMB exchange rate means the appreciation of the RMB is conducive to imports, while the decline of the RMB exchange rate means the depreciation of the RMB and the decline of the price of export commodities, so it has a greater price advantage and is conducive to exports. Chinese enterprises should correctly grasp the rise and fall of RMB exchange rate and carry out import and export trade reasonably when developing abroad.

import and export trade.

\section{Analysis of the Influence Principle of RMB Exchange Rate Fluctuation on Import and Export of Chinese Enterprises}

\subsection{The Operation Mechanism of RMB Apprecia- tion}

The situation of the appreciation of the renminbi will show up in the overall positive domestic economy development situation in our country, the economy is relatively stable period, the appreciation of the renminbi makes a unit of currency can buy more foreign products in international market, at this time, China's enterprises should be

*Corresponding Author:

Chao Gao,

Professor title: Doctor;

Zhejiang International Studies University, Hangzhou, Zhejiang, 310000, China;

E-mail:gchao503@126.com. 
more actively import foreign products, rather than exports. If the export of Chinese enterprises is increased at this time, it will lead to the purchase of Chinese goods by enterprises in other countries, they need to spend more money, so that the same unit of dollar currency can buy fewer goods than the earlier period. Although the appreciation of RMB has improved the status and discourse power of China's currency in the international market, it has also made foreign enterprises need to buy the same amount of products with more funds, and the price advantage of China's export has gradually disappeared. At this time, if the export volume is increased, good results often cannot be achieved ${ }^{[1]}$.

\subsection{Operation Mechanism of RMB Depreciation}

Depreciation, exchange rate drops, foreign companies can use a unit of dollars to buy more products in our country, it shows that our country enterprise product prices fell, from the domestic market, although our country's products are the same, the buying power of a currency unit but in terms of foreign markets, our product is lower than the price of before, therefore, depreciation brought export opportunities for our country. Our country enterprise should seize this development opportunity to carry on the active production, expands the foreign trade export volume, then promotes the enterprise own development. The decline of RMB exchange rate shows that China's currency depreciates, so it has a certain advantage in the price of products. Export enterprises can make use of this advantage to fight a good price war. Thus to a certain extent stimulate the export of our products.

\section{Analysis on the Channel Influence of RMB Exchange Rate Fluctuation on Trade Balance}

\subsection{Affect Commodity Import and Export Price}

The exchange rate changes of RMB are reflected in two aspects: appreciation and depreciation, and the appreciation and depreciation of RMB will affect the import and export trade of enterprises to a certain extent, and then affect the level of China's economic development. Two important factors need to be taken into account when the RMB exchange rate changes and Chinese enterprises adjust the import and export trade volume and related policies. First, the temporality of transmission. It takes a process from the adjustment of currency exchange rate to the price pass-through of import and export commodities. Although the change of exchange rate will affect the actual import and export trade, it takes a certain time. Therefore, although the changes in the price of financial assets caused by the exchange rate fluctuations will show its effect quickly, it is a slow process to affect the import and export of commodities, and the price changes of import and export commodities caused by the exchange rate fluctuations will take some time to show. Second, the balance of trade. The price of import and export commodities driven by the change of RMB exchange rate will affect the trade balance to a certain extent. The international market economy is extremely complex, and changes all the time. The RMB exchange rate also changes all the time. The price of import and export commodities will also adjust with the exchange rate changes due to the impact of the RMB exchange rate changes, which affects the balance of payment of import and export trade of Chinese enterprises to a certain extent ${ }^{[2]}$.

\subsection{Affecting National Income}

With the development of economic globalization and integration, national income will also be affected by RMB exchange rate fluctuations. For example, the depreciation of RMB will lead to the decline in the price of export commodities, which requires enterprises to actively export to foreign countries. However, for imported commodities, the same capital can buy fewer commodities. In this way, the nominal income level of Chinese citizens also shows a downward trend. With the same share of money, we can only buy fewer goods, which reflects the decline of the actual purchasing power and the decline of residents' disposable income.

\section{The Stage Analysis of the Influence of RMB Exchange Rate Fluctuation on Import and Export of Chinese Enterprises}

\subsection{Analysis on the Fluctuation of RMB Exchange Rate and Enterprise Import and Export Trade from 1994 to 2005}

In 1994, due to the need of economic development and penetrate the international market in our country, the national official exchange rate and the market rate of the renminbi have been adjusted, will be the official exchange rate and the market exchange rate, which caused the RMB exchange rate continued to fall, the behind reason is that our country economy development condition in the developed countries economic development and far, especially with the development of the U.S. economy. However, the devaluation of RMB has also led to a sharp increase in China's export volume, promoted the rapid development of China's foreign trade, and constantly presented trade surplus ${ }^{[3]}$. Since 1995, China's RMB exchange rate grad- 
ually began to appreciate slightly. Although the overall situation of China's economic development was not very good at that time, the export commodities still accounted for a large proportion in the international market and the trade surplus continued. Renminbi appreciation brought about by the reduction of commodity exports in China is not obvious. Although the economy has been developed to a certain extent, due to price factors, China's national income did not rise, the level of per capita income is still relatively low.

In 1997, affected by the Asian financial crisis, the currencies of Southeast Asian countries began to depreciate on a large scale. In order to maintain the balance of the Asian economy, China kept the exchange rate of RMB against the US dollar stable in the adverse economic situation. From the perspective of the economic environment at that time, RMB actually showed an appreciation. The growth rate of export trade is only $0.5 \%$, and the import trade even has a negative growth, which has caused a great impact on the development of Chinese enterprises. In 1999, the domestic economy began to recover, the country actively responded to the import and export trade, the import and export trade volume showed varying degrees of increase, the RMB exchange rate also maintained a very stable trend but slowly increased. Generally speaking, from 1994 to 2005, the RMB exchange rate continued to appreciate slowly in the fluctuations, which had a certain impact on China's export trade. However, due to the introduction of a series of policies and regulations and the obvious advantages of the high quality and low price of China's export commodities, the RMB appreciation did not have a substantial impact on China ${ }^{[4]}$. Table 1 can reflect the overall situation of China's foreign trade from 1994 to 2005.

Table 1. Overall situation of China's foreign trade from 1994 to 2005

\begin{tabular}{ccccc}
\hline Year & $\begin{array}{c}\text { Exports (\$100 } \\
\text { million) }\end{array}$ & $\begin{array}{c}\text { Proportion of } \\
\text { export growth }\end{array}$ & $\begin{array}{c}\text { Imports (\$100 } \\
\text { million) }\end{array}$ & $\begin{array}{c}\text { Proportion of } \\
\text { import growth }\end{array}$ \\
\hline 1994 & 1210.1 & & 1155.2 & \\
1995 & 1487.8 & 0.22949 & 1320.8 & 0.14335 \\
1996 & 1510.5 & 0.01526 & 1388.3 & 0.05111 \\
1997 & 1827.9 & 0.21013 & 1423.7 & 0.02550 \\
1998 & 1837.1 & 0.00503 & 1402.4 & -0.01496 \\
1999 & 1949.3 & 0.06107 & 1657 & 0.18155 \\
2000 & 2492 & 0.27841 & 2250.9 & 0.35842 \\
2001 & 2661 & 0.06782 & 2435.5 & 0.08201 \\
2002 & 3256 & 0.22360 & 2951.7 & 0.21195 \\
2003 & 4383.7 & 0.34635 & 4127.6 & 0.39838 \\
2004 & 5933.7 & 0.35358 & 5612.3 & 0.35970 \\
2005 & 7620 & 0.28419 & 6601.2 & 0.17620 \\
\hline
\end{tabular}

\subsection{Changes of RMB Exchange Rate and Export Trade of Enterprises from 2005 to 2013}

\subsubsection{Analysis of the Factors of Rmb Appreciation}

2005 was another key period for the RMB exchange rate fluctuation in China. The People's Bank of China announced that the floating exchange rate system of currency adjustment was introduced based on market supply and demand. The influencing factors and the conversion unit of RMB exchange rate fluctuation were no longer just US dollars. And announced on July 12 that the net value of China's RMB exchange rate against the US dollar rose rapidly by 2 percentage points. During the period from 2005 to 2013, the RMB showed a continuous appreciation trend, mainly for the following reasons.

The floating exchange rate system reform in 2005 made the exchange rate fluctuation of RMB need to refer to the currencies of 8 major countries in the world in a basket of currencies, rather than one currency of US dollar. With further push the floating exchange rate system reform and the formation of the market price mechanism, making China's RMB exchange rate to determine the need to further follow up the economic development level, and with the level of domestic economic development as the important reference basis, in addition, influence increasing in our country in the world, and further enhance the position of the world. (2) the development of domestic economy, further enhance the standards of China's foreign trade, per capita GDP growth, the international investment and trade environment continue to improve, in the developed countries also gradually changed the part about China's economic development will have a negative impact to the world economy, many developed countries have agreed that China is a country with a high investment potential, foreign capital into our country continuously, created a good environment for the appreciation of the renminbi. (3) The export advantage caused by the low RMB exchange rate makes the export trade of developed countries face great pressure. If the RMB exchange rate has not been effectively improved, China's export trade volume continues to rise and grow steadily, which poses a great threat to the exports of Japan, the United States and other developed countries. Under the influence of various pressures and factors, China's RMB exchange rate ushered in a continuous rising trend.

\subsubsection{Analysis of the Change of Export Trade of Chinese Enterprises}

As can be seen from Table 2, from 2005 to 2008, the trade volume of export continued to grow. 
Table 2. Overall situation of China's export trade from 2005 to 2013

\begin{tabular}{ccccc}
\hline Year & $\begin{array}{c}\text { Exports } \\
\text { (\$100million) }\end{array}$ & $\begin{array}{c}\text { Proportion } \\
\text { of export } \\
\text { growth }\end{array}$ & $\begin{array}{c}\text { Imports(\$- } \\
\text { 100million) }\end{array}$ & $\begin{array}{c}\text { Proportion of } \\
\text { import growth }\end{array}$ \\
\hline 2005 & 7620 & & 6601.2 & \\
2006 & 9689.8 & 0.27163 & 7914.6 & 0.19896 \\
2007 & 12204.6 & 0.25953 & 9561.1 & 0.20803 \\
2008 & 14306.9 & 0.17225 & 11325.7 & 0.18456 \\
2009 & 12016.1 & -0.16012 & 10059.2 & -0.11183 \\
2010 & 15777.5 & 0.31303 & 13962.8 & 0.38806 \\
2011 & 18983.8 & 0.20322 & 17434.8 & 0.24866 \\
2012 & 20487.1 & 0.07919 & 18184 & 0.04297 \\
2013 & 22090 & 0.07824 & 19499.9 & 0.07237 \\
\hline
\end{tabular}

In this period of time, the mechanism of a basket of currencies and floating exchange rate mechanism of RMB has been a growth, and the flexibility of the RMB exchange rate gradually strengthen, can be found by comparing the export trade and import trade, our country has been showing a trade surplus, it has to do with the influence of the traditional exchange rate changes on import and export trade is not consistent. During 2008-2009, both export trade and import trade showed negative growth, which was largely related to the international financial crisis in 2008. From 2010 to 2013, China walked out of the negative impact brought by the economic crisis and realized a continuous increase in import and export trade. Although the trade surplus shrank sharply in 2010 and 2011, it has steadily widened since 2012.

From exchange rate movements on import and export trade mechanism, the influence of the appreciation of the renminbi should reduce the export trade, and increase the import trade, through the analysis of the import and export trade of our country in recent years, we found that: (1) the appreciation of the renminbi has constantly optimize the structure of the import and export trade in our country, enable enterprises to adapt to the domestic industrial structure adjustment on the adjustment of trade structure, thereby lowering the dependence to foreign goods, in order to realize our country enterprise further development. (2) The continuous growth of trade surplus promotes the development of national economy in a healthy and positive direction. China constantly adjusts the structure of export commodities, and makes reasonable use of foreign exchange reserves on the basis of the rise of RMB exchange rate. (3) The rise of RMB exchange rate makes the products purchased per dollar become less. Although it affects the interests of China's foreign exports to a certain extent, it can effectively alleviate the trade friction caused by the continuous surplus. Such as the United States and other developed countries for China to set multilateral trade barriers and restrictive trade measures, and effectively promote the development of China's import and export trade.

\subsection{Changes of RMB Exchange Rate after 2014 and Import and Export Trade of Enterprises}

In March 2014, the RMB began to depreciate, and in August and September 2015, the RMB greatly depreciated, which had a great impact on China's economic development. From the internal reasons, it was related to the weak international economy and a large amount of capital outflow in China. Since 2014, China has paid more attention to the construction of ecology, politics, spiritual civilization and other aspects. Although economic construction is still the center, the development mode of seek improvement in stability has been adopted, and the economic development speed has slowed down. Therefore, RMB devaluation is inevitable ${ }^{[5]}$. From the perspective of external reasons, the European economy has not yet come out of the economic crisis. In order to stimulate domestic consumption and promote economic growth, a large number of euros have been issued, and the dollar has continued to appreciate. All these reasons have resulted in the depreciation of China's RMB. On the other hand, the devaluation of the RMB has further stimulated China's foreign trade. Chinese enterprises can take advantage of this opportunity to export products and occupy the international market, which has eased the export pressure of China and further expanded the export trade volume, and also played a positive role in alleviating the employment pressure of China. The disadvantage is that the decline of RMB exchange rate makes China need to spend more money to buy the same foreign products, which brings severe challenges to the development of import enterprises. As the cost of foreign investment increases, the cost of imported products will also increase, which continues to increase the trade friction between China and some countries.

\section{Conclusion}

To sum up, based on the RMB exchange rate, the change of import and export trade will cause certain influence to our country enterprise, whether the appreciation of the renminbi, or RMB devaluation, China's enterprises import and export trade need according to the interna- 
tional market environment as well as the national policy to make corresponding adjustment, so as to promote the development of our economy, and promote our country enterprise better to go out.

\section{References}

[1] Wang Yuecheng, Zhang Bojiang.Analysis of the impact of RMB exchange rate fluctuations on China's import and export trade [J]. Modern Finance, 2020(07):26-28.

[2] $\mathrm{Hu} \mathrm{Xu}$. Impact of RMB exchange rate fluctuations on
China's import and export trade [J]. Time Finance, 2020(10):55-56.

[3] Guo Yu. The Impact of RMB Exchange Rate Fluctuation on China's Import and Export Trade [J]. Journal of Pu Er University, 2019,35(02):19-20.

[4] Zhang Shangsheng. The Impact of RMB Exchange Rate Changes on China's Import and Export Trade Structure [J].Knowledge Economy, 2018(24):41-42.

[5] Cui Nan. Analysis on the Impact of RMB Exchange Rate Fluctuation on China's Import and Export Trade [J].Modern Economic Information, 2018(12):140. 